\title{
ACARICIANDO A CONTRAPELO LOS 70. EL ARCHIVO EN HISTORIA DEL LLANTO DE ALAN PAULS
}

\author{
María José Sabo \\ Universidad Nacional de Córdoba. CONICET \\ merisabo@hotmail.com
}

RESUMEN / ABSTRACT

El artículo aborda desde una mirada ensayística y analítica la novela de Alan Pauls, Historia del llanto. Un testimonio (2007), pensándola como una novela-laboratorio en la que se indagan y proponen otras formas de escribir la memoria. Por un lado, desde el protagonismo del cuerpo, particularmente aquí las lágrimas y la piel; por otro, en confrontación a la idea de una reconstrucción del pasado como mecanismo de reparación del trauma social y, asimismo, interpelando la concepción de un arte al servicio de la representación y la conciliación de sentidos. Para ello, la hipótesis de lectura propone leer la novela como texto que opera una continua desestabilización del archivo de formas de representación del pasado, efectuando un extrañamiento incómodo de las lecturas con que la discursividad social del presente ha consensuado medianamente un relato de los años 60 y 70 . La novela busca escribirse desde el encuentro con aquellos otros materiales que el archivo, para su constitución y eficacia, ha borrado, olvidado o no dicho. A través de los aportes de Jacques Rancière y Jean-Luc Nancy a la indagación estética, como también haciendo referencia a los aportes de Michel Foucault y Hal Foster, entre otros, a la problemática del archivo, es posible inscribir la novela en un trabajo con los materiales del pasado renuente a la clausura de sentidos: una escritura que busca mantener el relato de la memoria como un ejercicio siempre en proceso y atravesado por la poética de los cuerpos en contacto, por ende, sujeto a pugnas que lo reinscriben en la arena política.

PALABRAS ClaVE: archivo, memoria, restos, expielsición, representación.

The aim of this paper is to address Alan Paul's 2007 Historia del llanto. Un testimonio from an essayistic an analytical perspective, considering it as a laboratory-novel that enquires and suggests other means for memory writing. On one hand, we look into the relevance of the 
body, particularly of tears and skin. On the other, re-writing memory is viewed as a form that confronts the idea of past reconstruction as a social trauma reparation device. In addition, the novel questions the conception of art at the service of representation and conciliation of meaning. Therefore, we propose to read this work as a text that destabilizes representational forms of the past archive. The effect of this is an uncomfortable estrangement of the means by which actual social discourses have partially come to terms with a narrative about the 1960s and 1970s in Argentina's recent history. The novel looks for those other materials which the archive, in order to constitute itself and be efficient, has deleted, forgotten or left unsaid. Taking into account the contributions to aesthetic enquire by Jaques Rancière and Jean Luc-Nancy, as well as the ideas by Michel Foucault and Hal Foster to archive issues, the novel can be regarded as a work dealing with past materials and reluctant to suppress meanings. The novel arises as a writing style that intends to keep memory account as an ever-processing exercise crossed by a poetics of bodies in contact. The narration of memory will be subjected to the struggles that replace it into the political arena.

KEY WORDS: archive, body, memory, representation, remainder, ex-peau-sition.

La sensibilidad condensó para la militancia revolucionaria de los 60 y 70 un horizonte de múltiples expectativas de cambio social y político. Ésta encarnó la consigna de la revolución social desde su aporte a la utopía de una nueva comunidad anti-disciplinar fundada en la campechanía, humanismo, solidaridad y sinceridad. En este sentido, junto con la formación libresca en los teóricos marxistas, constituyó el pilar de una pedagogía capaz de organizar las experiencias subjetivas de estos años.

Para alivianar el abordaje de estas décadas de su carga de documentalidad profusa y (re)interpretaciones continuas, la novela Historia del llanto (2007) de Alan Pauls abreva en este costado poco transitado por las escrituras de la memoria; la educación sentimental sesentista y setentista en relación con la conformación del sujeto militante, a un sentido de comunidad y de revolución social, buscando astillar la imagen cristalizada con que el presente reconstituye estos años a partir del relato ampliamente consensuado de la utopía cancelada por la violencia militar. El texto propone resquebrajar aquellas imágenes que compensan, remedian una derrota difícil de asumir culturalmente, en ese sentido, nada más alejado que la nostalgia en su mirada hacia el pasado.

Para ello, la novela no deja de dar cuenta -aunque siempre desde su continua interpelación- de un corpus de lecturas, discursos, pero también géneros y soportes que, emplazados en el espacio público de la posdictadura y atravesando de múltiples modos la discursividad social, han sedimentado un repertorio de formas de representación consensuadas de estos años y destinadas a la reparación del lazo social. Formas sin duda diversas y múltiples, pero 
convergentes en la concepción de que para sanar es necesario reconstruir. A este corpus de lecturas le denomino el archivo de los años 60 y 70 , el cual, en tanto conformado a partir de un sistema de reglas que administran lo decible y lo no decible (tomando aquí el concepto de Michel Foucault, nos referimos entonces al "sistema archivístico" (218-221)), genera indefectiblemente aquello que Jacques Rancière denomina como "un reparto específico de lo sensible" (Rancière, Las paradojas 53-85), es decir, una manera de entender que torna disponibles ciertos mecanismos de apropiación (53-85), en este caso del pasado y de inscripción en él. Quisiera proponer como lectura de la novela que ésta no solo busca desestabilizar este archivo yendo al encuentro de aquello olvidado o no dicho/decible en él, sino que a la vez interpela la propia posibilidad de una representación que reconstruya ese pasado inscribiéndolo en la tarea de recomposición del lazo social.

\section{ENSAYAR OTRO CUERPO, ESCRIBIR OTRO RELATO}

En Historia del llanto, la sensibilidad se convierte en un punto extremadamente significativo para relevar la inscripción de la política en el cuerpo y en lo íntimo-familiar. En ella, la educación en una afectividad es índice de un modelo de cuerpo receptivo, abierto, soporte de una intensidad biológica -a la altura de la intensidad que exigía la oportunidad histórica de la Revoluciónque en tanto, por la forma en que se pone de manifiesto en el texto, parece colindar con un afuera del logos, se resuelve en el puro acto de las secreciones primarias: llanto, vómito, eyaculación ${ }^{1}$. Éstas ocuparán un lugar nodal en la novela, las dos primeras por su protagonismo constante, ya que la mayoría de los personajes lloran, algunos discretamente y otros de forma desmesurada, también porque el llanto constituye formas de filiación y pertenencia como detallaré posteriormente. Por su parte, la náusea y el vómito también están presentes en la propia corporalidad del personaje principal y en la forma en que el sustrato humanista-naïf que la novela busca poner en evidencia

\footnotetext{
También hay una referencia en la novela a una extraña reticencia del personaje principal a sudar (31). Aunque solo se alude a ella remitiéndola a un futuro impreciso, resulta inquietante porque supone un control sobre un funcionamiento corporal autónomo de la conciencia. La hipérbole con que en la novela se trabajan las funciones secrecionales del cuerpo tiende justamente a desautomatizarlo y operar sobre él un extrañamiento permanente.
} 
vehiculizando allí una crítica al idealismo político de los 60 , podría resumirse en un "sacar todo afuera" (una frase repetida en varios episodios del texto para aludir literalmente al vómito, pero también para construir un paralelismo con la necesidad "expresiva” en los personajes), transformando en vómito incluso las confesiones que los demás personajes hacen al personaje principal, el testigo-confidente. Mientras que la importancia de la última se halla más relacionada a su negatividad, a una ausencia que delata un orden social y cultural sostenido sobre la forclusión de la sensualidad como verdadera apertura al encuentro gozoso con el otro: la incapacidad de la mentada sensibilidad sesentista de devenir sensualidad, exceso de vida. En la novela, solo un episodio reducido al mínimo de detalles -contrastando por ello con el espacio narrativo que ocupan las demás manifestaciones corporales- relata un encuentro sexual pleno descripto como La Felicidad, sin embargo, es una felicidad individual que no deja de alimentar la máquina de dolor que, desde la óptica del texto, abrigan estos años.

En la novela, la educación sensible se constituye también, perversamente, en el umbral de una educación en y por el dolor. Un punto en el que las utopías nos devuelven su rostro más insospechado. De ahí que para el personaje principal "el dolor [sea] su educación y su fe. El dolor lo vuelve creyente. Cree solo o sobre todo en aquello que sufre (16), y más adelante reafirma, "una sensibilidad que solo tiene ojos para el dolor" (19). La entronización cultural del dolor en tanto energía tanática que modula las relaciones es ya una brecha crítica respecto a los relatos que reifican los sesenta como utopía incontaminada, interrumpida por una coyuntura externa, por un terror venido desde un afuera impensable.

Es precisamente esta doble faz perturbadora de la educación sentimental sesentista la que se procura la novela como vía de acceso oblicua a una época ya tan sellada por lecturas reconstructivas y celebrantes de su herencia de idealismo.

Pero Historia del llanto no busca "agregar” nuevos sentidos más o menos olvidados a ese friso de lecturas consensuadas, por el contrario, no deja de problematizar el consenso tranquilizador y edificante respecto al pasado, reabriendo su archivo para desestabilizar y volver a presentar estos años como herida abierta, como piel irritada: una revolución que no sublevara la distribución de los cuerpos en el espacio social y político constituía ya una utopía conservadora y derrotada.

En este sentido nos topamos con la resonancia de otras escrituras iconoclastas a un credo en la Revolución desentendido de su anclaje corporal como son 
la de Manuel Puig, El beso de la Mujer Araña, y Néstor Perlongher, cuando señala la hiposensualidad argentina como sustrato profundísimo de pacatería y microautoritarismo social consensuado (Perlongher, 13-21).

A partir de un relato en tercera persona, la novela comienza temporalmente a principio de los años sesenta focalizada en un personaje que por entonces es un niño de cuatro o cinco años. Otros episodios ubicados alrededor del significativo año de 1973 harán referencia a distintas situaciones específicas de una educación sentimental en el marco de la adolescencia del personaje, y por último, hacia 1981, una referencia a su adultez desencantada. El borramiento de las marcas temporales en la novela no es total, pero sí suficiente para hacer evidente que su opacidad es intencional en tanto motoriza una pesquisa del sentido atenta a los silencios. A través de este borramiento se presiona a una lectura de los 60 y de los 70 sin la profilaxis de la distancia histórica, por el contrario, la intromisión incómoda del presente parece ser la única posibilidad de volver al pasado. Así, temporalmente la novela no solo es compleja porque siendo su referente el pasado, éste es trabajado desde un presente continuo, sino porque además todos los episodios, en vez de proseguir una línea de vida, un continuum que permitiera leerlos como acumulación y superación de etapas, se hallan salpicados sin orden a lo largo del relato, reproduciendo la energía caótica y disruptiva del recuerdo.

Porque el recuerdo debe estar vivo, latente/latiendo -tal como su propia etimología encierra, traer de nuevo al corazón- como una húmeda y porosa membrana, si no, como expresa el narrador, "pierde vitalidad, se deshidrata y contrae, igual que se reseca el órgano extirpado si no lo acoge pronto el tejido pletórico de sangre y nervios de un organismo nuevo" (59). La novela trabaja con esta concepción orgánica y vital del recuerdo. Por ello, los episodiosrecuerdos, muchos de ellos en verdad solo imágenes sin acción, retornan y chocan entre sí irritando el tejido biológico de los cuerpos y haciendo que la experiencia del personaje se vea siempre sujeta a revisiones o a rectificaciones que socavan el tradicional relato biográfico del (aspirante a) militante.

Este personaje-héroe, aunque central, nunca queda sujeto ni a un relato biográfico que monumentalice su vida ni menos aún a la definición de un nombre propio, como también ocurre con los demás personajes a los cuales conocemos por medio de referencias esquemáticas o estereotipadas que aluden parcamente a funciones sociales y familiares (madre, padre, abuelos, novia/s, amigo/s, vecino, mucama), o por motes específicos (el oligarca torturado, el cantautor de protesta, la erpia) que, como sugiere Gersende Camenen, encarnan tipos, ideas o experiencias de la época. El único personaje que recibe 
nombre y que es portador de una biografía reconstruida es la víctima total: el vecino-mujer guerrillera. Que sea el único personaje con un nombre, el cual además se revela a solo tres páginas de concluir la novela, "la comandante Silvia", lo desmarca vertiginosamente de la ficción, haciendo ingresar en el texto la tensión que opera el impulso archivístico hacia la documentalización y sutura de la vida en el marco de lo biográfico.

En el resto de los personajes, el borramiento de la marca específica y socialmente valorada de la subjetividad que constituye el nombre propio no solo va a contracorriente de la tradición de la novela de formación clásica, género interpelado en Historia del llanto, sino que también contribuye a una progresiva disolución del pacto biográfico que la expectativa lectora busca constantemente en razón de la promesa que lanza el propio subtítulo de la novela: Historia del llanto. Un testimonio.

Asimismo, pocas peripecias, es decir, pocos puntos narrativos capitalizables para la conformación del perfil de un héroe, constituyen el paisaje de una niñez en el seno de una familia burguesa de padres separados, madre depresiva adicta a las píldoras y abuelos sumidos en la rutina de la indiferencia mutua y el hastío de la vida. Las escasas peripecias son trabajadas como si fuese a través de una cámara que permanentemente hace zoom sobre ellas -llevando al relato hacia la potencia de la visualidad-, aumentando los detalles nimios y sobrecargando las frases.

Un recuerdo que proviene del paisaje de niñez del personaje y que palpitará a lo largo de toda la novela, el de las salidas con el padre a las piletas de distintos clubes porteños de la época, de cuyo marco se desprende una de las imágenes capitales del relato: el sumergimiento ritualizado del niño hasta el fondo de la pileta para tocar con la punta de sus dedos la gran boca de un pulpo de azulejos: la consecuente irritación de la piel de las yemas que se desgrana por ese roce y por el agua con cloro ensaya en el texto una poética de lo político en el cuerpo donde la relación con el otro supone un afinamiento de esa barrera última de pertenencia a una subjetividad, la pura membrana de piel.

La piel y el tacto adquieren cada vez mayor relieve. Tanto éstos como el llanto encarnan, literalmente, la pedagogía sentimental de estos años, pero a diferencia de los significados de contrición que se ciñen sobre el llanto de los diferentes personajes -y en especial por el rol que adquiere en la relación padre-hijo-, el tacto, convocado en el texto a reconfigurar la epistemología del cuerpo, abre la posibilidad de proyectar una forma de comunidad que rompa con aquello referido en la novela como "la 
comunión del llanto 2 ”, donde lo común es el dolor. En contraposición a ello, como afirma Jean-Luc Nancy, ningún contacto con una piel está exento de una caricia en potencia (Archivida 20).

En la novela, el con-tacto, como experiencia intrínsecamente somática, llega hasta el punto de enajenar “el propio cuerpo” y "lo propio” del cuerpo, volverlo un mapa extrañado de sensaciones que irrumpen y tajean su identidad y su estabilidad material. Así, el personaje en reiteradas ocasiones se mira asombrado la piel ajada y llena de finos hilos de sangre de sus manos: "modestísima como es, la superficie de las yemas paspadas de sus dedos no tarda en estar para él tan llena de secretos como el cielo nocturno para un astrónomo" (19).

Cuando el vecino acoge al niño en un abrazo de contención maternal, luego de que éste hubiere vomitado en el ascensor avergonzando a su madre, el estremecimiento de ese con-tacto que se reconoce en la porosidad de su cuerpo, de sus yemas adelgazadas y enrojecidas, lo sacude como si hubiese quedado expuesto en toda su intimidad:

[el vecino] mientras canta le ha tomado las manos heladas para frotárselas, sin pensar, naturalmente, que en las yemas de los dedos encontraría esas rayitas verticales rojas que no le pasan inadvertidas, que examina de cerca y roza apenas con las yemas de los suyos, como si sólo lo mismo pudiera conocer y curar a lo mismo, hasta que él, sobresaltándose, retira los dedos avergonzado, con el último aliento que le queda, antes de sucumbir a la canción y caer dormido" (82).

Esta piel con piel se repetirá como ritual inconfesado entre ambos cuando, cada vez más asiduamente, el niño quede al cuidado del vecino en su departamento:

prepara las manos volviéndolas palmas arriba sobre el manubrio [de su triciclo] y lo espera, le roza las yemas de los dedos como si le midiera el grosor de la piel, el grado de erosión (...) la distancia que separa en su cuerpo el exterior del interior, el umbral del dolor" (110-111).

\footnotetext{
Señala Jean-Luc Nancy (La comunidad inoperante) que la idea de comunión como lazo aglutinante de lo social remite, por su resonancia cristiana, al restablecimiento de una supuesta unión primordial, una autenticidad perdida que funciona como esencia. Para el filósofo, es necesario cambiar este esquema en la medida en que no hay nada auténtico perdido, la pérdida es lo constitutivo de la comunidad. Nancy propone pensar el surgimiento de la comunidad (no inmanentista) desde la exposición (J.L. Nancy. La comunidad inoperante).
} 
Es precisamente, como propone Nancy (Archivida 16-20), la desestabilización del límite entre el adentro-afuera del cuerpo lo que hace que el tacto sea un sentido único. A diferencia de la unidireccionalidad corporal que impone, por ejemplo, la vista o el olfato, cuando el cuerpo, la mano "toca", también "se toca”, se acaricia, se experimenta desde el afuera. Es decir, es una sensibilidad recíproca donde la piel se siente sentir en una coproducción de los cuerpos a partir de lo que pasa (por) entre ellos sin anular la distancia que lo hace posible. En otras palabras, tomando los aportes de Rancière a la estética, sin “saturar el reparto de lo sensible” (Las paradojas, 53-85), preservándolo de este modo como tarea por venir para que la política, entendida como disenso permanente, sea posible ${ }^{3}$.

Cuando ya adolescente descubra el rostro de este vecino en el rostro de la mujer guerrillera que aparece desnuda, acribillada y tirada en un descampado en una de las páginas de La causa peronista, revista oficial de Montoneros que lee con fruición, serán nuevamente las yemas de sus dedos las que acaricien esas letras y la imagen (Pauls 122), trayéndole así al presente, como un torbellino, todas las otras imágenes del recuerdo: el bigote falso del vecino cayéndosele, sus pies y manos demasiado pequeños para ser hombre, la imperfección de su uniforme militar delatándola, los muebles vacíos de su departamento certificando la utilería en que camuflaba su clandestinidad. El roce de esos dedos contra el papel, que es también el roce a contrapelo del recuerdo sobre el cuerpo, lo estremece al punto del llanto luego de años de sequedad, luego, incluso, de haber sido incapaz de llorar como hubiera querido ante la transmisión televisiva del bombardeo a La Moneda: “¿Llueve? No: llora. Llora en la ciudad como llueve en su corazón” (123).

El tacto es portador de una sensibilidad que, en la medida en que excede el cuerpo individual, conforma una dimensión colectiva, vinculante, de afectos, deseos, una sensualidad y erotismo que no busca la clausura de la subjetividad, sino que se abre hacia la exposición, ex- piel- sición ${ }^{4}$ propone Nancy (Archivida 25) como un darse al afuera y un (re)hacerse incesante a través del vínculo.

Al reconocer a su vecino en la imagen de la guerrillera asesinada se pregunta y fantasea qué habría pasado si en alguna de esas largas tardes que

3 Para Nancy, la “fusión” con el otro pertenece al orden del totalitarismo, es decir, a la comunidad inmanentista.

$4 \quad$ En francés, ex-peau-sition, se acerca a la huella fonética de exposición en español. 
pasaban a solas - una intimidad que en este siniestro mundo contenido en la novela hubiera invitado al abuso, a las perversidades-ella, en vez de "limitarse a ofrecerle el tazón de sopa”, le hubiera metido los dedos, la lengua en la boca para tocarlo "del lado de adentro", o si "lo hubiera obligado a meterle una de sus manitos de niño abandonado hasta el fondo último, húmedo, de la concha" (124). El tacto abre en el texto un espacio para pensar el lazo social desde lo que sucede entre los cuerpos, funcionando así la novela como un laboratorio experimental desde el cual ensayar otras epistemologías sobre éstos que desestabilicen el archivo-legado de estos años. Abierto al con-tacto y a la potencia del advenir, el cuerpo entra en una permanente posibilidad de reformulación, de re-hacerse con los otros. En este sentido, también la conformación del lazo social en tanto aquello (en) común que hace que estemos juntos, busca ser redefinido en la novela interrogando lo que en ella se concibe como la utopía pedagógica de estos años. Mientras su prerrogativa era imprimir sus buenas intenciones sobre un cuerpo que, así, quedaba sujeto a un dogma y a una utopía, intenciones además sostenidas en los indiscutibles y urgentes valores del entendimiento y la conmiseración humanista, esta educación sentimental parece en verdad haber enlazado los cuerpos al imperativo del dolor como escuela a través de una "comunión del llanto”. Por otra parte, si construir lo común desde la expielsición posibilita pensar los cuerpos en su reformulación, también el relato que se re-escribe incesantemente a través suyo deberá permanecer en proceso, socavando los puntos de anclaje identitario y las esencias sublimantes de lo material-corporal. Mientras en general las matrices narrativas que han acaparado y formateado la transmisión y el acceso a este pasado reciente en el espacio público como el testimonio, las biografías, ensayos y artículos periodísticos, trabajan más en la clausura que exige lo verídico/verificable, generando repertorios de subjetividades, unificando rasgos (la heroicidad, el idealismo, la entrega del militante por ejemplo), y modelos biográficos, los cuales funcionan como asidero de un discurso apremiado por la construcción del sentido, Historia del llanto en cambio ensaya, rasgando la serie de reglas que en determinado tiempo y lugar definen qué se puede hablar, cómo y quiénes (Foucault 218221), una apertura hacia lo todavía por decir y hacia lo no dicho a través de un sostenimiento del tiempo presente que hace de esta palabra un significante inarchivable.

Esta tensión tiene lugar dentro de la propia novela cuando el personaje principal lee en La causa peronista el epígrafe que acompaña y sella la fotografía de la guerrillera acribillada/ vecino: 
Comandante Silvia (...) infancia en la provincia de Tucumán, madre maestra, padre empleado de correo, visita de Evita y deslumbramiento, Revolución Libertadora y caída de Perón, padres presos, tío en la resistencia, mudanza a Buenos Aires, encuentro con Cooke, la clásica biografía de la que está llamada a vencer o morir (122) .

Una modalidad de reconstrucción biográfica que norma, paradójicamente, aquello que a su vez exhibe como la excepcionalidad de estos jóvenes-héroes. La centralidad de las elecciones tempranas, de los valores emanados desde el seno familiar, el "deslumbramiento" como momento iniciático que marca a fuego una trayectoria vital entregada a la lucha, la cual, a su vez, otorga coherencia a esta vida y la vuelve obra, son instancias de un relato biográfico extensamente repetido en los discursos de la memoria que refieren a estos años. Un texto paradigmático de ello es sin dudas La Voluntad. Una historia de la militancia revolucionaria. Tomos I, II y III (1997-1998) de Martín Caparrós y Eduardo Anguita, cargado de este tipo de biografías donde los encuentros con personajes históricos clave, la resignación de la comodidad individual en pos de la lucha por cambiar el mundo, la entrega de la vida, la sensibilidad social, etc., por su propia repitencia sine qua non, terminan configurando rasgos que definen una pertenencia del ser (militante) a una esencia que los precede (a la que están destinados, "llamados” como dice el extracto arriba citado). De este modo, son sujetos (el militante, el guerrillero, la víctima) que realizan la esencia a través de esa vida-obra, de otra manera, no tendrían cabida en un relato como el que propone La Voluntad. Y evidentemente no hay obra más acabada que el mártir ${ }^{6}$ : así como entre las páginas de La Voluntad deambula la enormidad humana de Rodolfo Walsh, también en la novela los personajes

\footnotetext{
5 Resaltado mío.

6 Quisiera abrir un paréntesis para detenerme en las reflexiones sobre el archivo provenientes del campo de las artes plásticas. Éstas señalan por un lado, la actual fetichización museística de los 70, en especial, en relación con el arte latinoamericano en la escena artística internacional. Por otro, la forma en que este giro archivístico operó paralelamente un desmantelamiento del binomio excluyente obra de arte/documento, fundamento estético, epistémico y curatorial del discurso tradicional de los museos. Mientras el documento era considerado una exterioridad/eventualidad a lo específicamente artístico (era "el camino hacia la perfección”), el museo estaba reservado para la obra excepcional, el resultado. Pero el impulso archivístico avanza sobre esta distinción incluso poniéndola al revés: haciendo del documento la obra. En este sentido, me parece interesante poder abrevar de esta cantera para seguir explorando aquello que al comienzo del trabajo hemos denominado "el impulso archivístico hacia la documentalización de vida" en la medida en que estos relatos biográficos
} 
lloran sus propios mártires doblemente afantasmados e inmaculados por la pantalla del televisor que transmite en directo la procesión de los cadáveres.

A contracorriente de esto, lo que impulsa al personaje principal es lo que Nancy refiere como acción inoperante, es decir, incapaz de hacer obra (Nancy, La comunidad inoperante). Siendo candidato a militante modelo, especialmente por su don inigualable de llorar y su capacidad de escucha tan celebrados por su padre, el personaje principal se escurre del libreto fijado para desdecir "sus esencias". Si primero "lo suyo es la sensibilidad. Escuchar, llorar, y a veces, muy de vez en cuando, también hablar" (33), luego decidirá que ya no, que no llorará más, y ni siquiera cuando se lo proponga podrá hacerlo porque "Ahora él no es el que llora: es el que hace llorar" (97). Una inestabilidad biológica (la capacidad de suspender el llanto o por el contrario, el dominio del llanto sobre el sujeto) y biográfica que cuando mira hacia atrás, al contrario de aquellas otras biografías encaminadas hacia una consolidación cada vez mayor de las decisiones primeras, solo ve, extrañado de sí mismo, "al idiota cándido que ya no es" (11).

Pero además, se halla distante de toda acción heroica y consagratoria, dedicado, por el contrario, a la lectura: "a los catorce es tan incapaz de dar el paso y entrar en la acción política como de apartar los ojos de todo aquello que celebra a su alrededor, imágenes, textos, periódicos, libros, testimonios en primera persona, narraciones noveladas, versión vibrante, llena de sangre, pólvora, coraje" (116). Podemos decir que su interés es estético, está fascinado por la mitología y el romanticismo de la guerrilla, se zambulle en la lectura de La causa peronista "con el corazón en la boca cada vez que vuelve del kiosco" (11) como cuando niño lo "obnubilaban los colores y las formas" (9) de las historietas de superhéroes. De ahí también el protagonismo de la imagen y la relación que éstas entablan en la novela con una percepción del tiempo.

Así, la lectura (de revistas clandestinas, de los teóricos del marxismo y de las revistas pornográficas, las cuales también entran a formar parte del mismo goce estético-corporal) en tanto no-acción ocupa un lugar central para el personaje, "como quien sigue el mejor curso de lucha armada por correspondencia" (120). Esta desavenencia frente al relato modélico de la época, el ungido paso a la acción, se traslapa en el texto hacia la posibilidad de pensar en una acción que no sea instrumental en el sentido de operante de

ponen en evidencia también una política expositiva del documento/obra (Ver especialmente Joaquín Barriendos, "Reterritorializando los sesenta" 121-141). 
una pertenencia, es decir, acciones que no hagan de la vida (del personaje) una obra acabada. Así, su "gran acontecimiento político", lejos de ser el encuentro iluminador con un personaje histórico, es su propia defección de la sensibilidad, su propio "darse vuelta como un guante" (62) que tanto placer le provoca cuando le ocurre a los otros.

Para Nancy, hay algo de sublevación socio-política en el tocar, “algo de insurrección, en efecto -y a veces algo de erección- en la moción del tocar. Un cuerpo se yergue contra su propia clausura, contra su encierro en sí mismo, contra su entropía. Se yergue contra su muerte” (Archivida 23). Por esta vía, la piel y el con-tacto abren en la novela posibilidades para pensar y desarmar la amalgama de pertenencias que sostiene lo biográfico: la fusión entre un cuerpo-una vida-un sentido.

De esta forma, frente al cuerpo desnudo e impenetrable de su amante, la “ex-erpia”* torturada en La Perla, él solo se detiene en una zona que brilla, donde la piel se alisa quedando sin poros, ni pelos ni accidentes, "cuatro centímetros cuadrados de membrana muerta" (99) que constituyen la cicatriz y el recuerdo de su suplicio, y en silencio pasa por allí la punta sus dedos. Este con-tacto con una piel que, en la medida en que es inerte, "pedazo de piel ciega" (100), se supone que "debería aislarla del mundo" (100), en otras palabras, volverla obra acabada y sentido clausurado sobre la esencia de ser, ante todo, una sobreviviente, sin embargo, lo que hace es re-abrirla, o mejor, como dice el propio narrador: "despellejarla" (100).

De hecho, la figura del sobreviviente permite adentrarnos de forma paradigmática en las tensiones estético políticas contemporáneas, ya que se halla inmersa en la disputa entre, por un lado, las poéticas/ éticas de lo irrepresentable, aquellas que abogan por un poner a resguardo de la vileza del mundo y del desgaste de lo cotidiano la gravedad de la tragedia, lo cual, como afirma Agamben, conduce paradójicamente al misticismo restaurador de su gloria (Homo Sacer III, 17), y por otro lado, aquellas poéticas de la representación que integran su testimonio a un proyecto de devolución de sentido a un mundo quebrado por la emergencia de un horror completamente fuera de lo racional y humano.

Distante a ambos modelos, en la novela el sobreviviente es traído constantemente al presente vivo, a la temporalidad del acontecer antiacumulativo

El personaje se refiere a su amante como "ex-erpia" aludiendo al pasado de ésta y su militancia dentro de la ERP (Ejército Revolucionario del pueblo), grupo guerrillero liderado por Mario Roberto Santucho durante la década del 70 en Argentina 
(de marcas, de identificaciones disponibles a representaciones reconfortantes). Este presente interpela la solemnidad, que también puede pensarse como una forma de intangibilidad, de la víctima y su relato. De hecho, cuando otro sobreviviente, el "oligarca torturado", se "confiesa" con el personaje, es tal el hostigamiento que siente por esas palabras que lo mueve a fantasear venganzas, a, textualmente, "entrar en acción y hacer[lo] polvo" (59).

Por ello, este texto-laboratorio en que se constituye la novela busca trabajar con materiales literarios renuentes a una representación reconfortante, en la cual ni los personajes y ni sus cuerpos se constituyan en portadores de ninguna esencia que los capitalice para un relato re-afirmativo. El pertenecer esencializado y privativo a una ideología, a una pedagogía, a un grupo, el definirse, clausurarse en esa pertenencia que supedita la potencialidad de la vida a una horma que delimita sus contornos y la uniformiza, los vuelve instrumentales a la rigidez repetitiva del mito.

Cuando en la novela aparecen indefectiblemente esas pertenencias demasiado ajustadas a los modelos preprogramados, el relato procura trabajarlos como máscaras tragicómicas. El "cantautor de protesta" -cuyo referente, por los guiños tales como su acento italiano, su retorno en 1981 y su aspecto particular, es sin dudas el cantante Piero- y el "oligarca torturado" -con una referencia mucho más opaca pero que por su cualidad de personaje contradictorio tal vez pueda evocarnos a Rodolfo Galimberti-, condensan, el primero, la irreprochabilidad humana del comprometido y el idealista, el segundo, la respetabilidad y redención del sobreviviente y la eximición que su eterno calvario le confiere de todo juzgamiento. Pero el texto barre con todo posible sustrato de humanismo para así abordarlos exponiéndolos a la intromisión del presente. De este modo, mientras el episodio con el cantautor pone de relieve la otra cara de la sensibilidad setentista transformada en revulsiva sensiblería así como también la carga de autocomplacencia, conformismo e ingenuidad de sus utopías, el episodio con el oligarca torturado no deja de señalar los grises de la Revolución que no fue y el después: el fracaso social y político reencantado por la panacea económica del neoliberalismo y la restauración del poder conservador del dinero.

Abrir el archivo es siempre abrirlo de forma crítica: una caricia a contrapelo que sin duda eriza la piel, pero a la vez, en ese tocarse tocando que la envuelve, la despierta ásperamente a la vida en la que el pasado y el presente se coproducen.

En este sentido, la pregunta por el lugar estético, político y social que ocupa el dolor en el imaginario de estos años es una de esas cicatrices que, 
como la de la "ex-erpia”, si bien parecen cerradas, mudas, al pasar por ella el texto, se reabre lo no dicho-no decible del archivo.

Y es el llanto el que en la novela nos permite explorar esta pregunta.

A través de la exageración y mecanización del llanto, lo cual desnaturaliza algo asumido como natural -y por ende, imperceptible como espacio crítico-, es posible abordar políticamente al cuerpo en tanto constructo de pedagogías destinadas -no sin violencia, no sin dogmatismo-a normar una sensibilidad, un modo de ser en/con el mundo: porque el llanto pasa a estar dentro de la órbita de todo aquello (ideología, posición política) “que por entonces es obligatorio tener, que nadie se puede dar el lujo de no tener" (84). Por ello, irrumpe de manera hiperbólica, compulsiva, desvinculada de cualquier acontecimiento u afecto real que lo justifique, en otras palabras, deviene mera imagen de una idea pedagógica.

En la novela, las lágrimas son la perturbadora hebra filial entre el padre y el hijo: "esa capacidad extraordinaria que tiene de llorar ante el menor estímulo (...) tiene la impresión de que solo la pone en práctica, incluso de que la posee, así, lisa y llanamente, cuando su padre está cerca" (30). A su vez, el padre la celebra y exhibe "frente a los amigos de su generación”, como si fuese una "función de gala" (33) porque allí [en el llanto] el niño se luce como un "semidiós", "campeón olímpico", un "niño prodigio" (33), "el llanto es la prueba, la obra maestra, el monumento, que [su padre] alienta y celebra y protege como si fuera una llama única" (30). Mientras que desde la óptica del niño, este llanto es una "ofrenda" (30) automatizada hacia su progenitor.

Estos distintos extractos textuales señalan su costado de espectacularización, donde el cuerpo es compelido a una forma estética cargada de valores (compromiso, empatía, humanidad). Este lugar del llanto se manifiesta incluso cuando, ya en la adolescencia, el personaje “envidia” el llanto que su amigo despliega frente a la pantalla del televisor que transmite en directo el bombardeo a La Moneda. Pero lo que envidia en verdad es netamente la expresión estética de ese dolor: "el circo alrededor, los lagrimales rojo sangre, las erupciones de rubor, los accesos de hipo que sacuden a su amigo, la saña desconsolada con que refriega las manos, el modo en que cada tanto se cubre la cara para ahogar, quizá para estimular, una nueva racha de lágrimas” (85).

De esta manera, el dolor acapara todo el reparto de lo sensible, se vuelve lo común, lo que los hace estar juntos: satura las formas del goce, prescribe las modalidades de la pertenencia (a una generación, a un repertorio de ideales y a una familia) y organiza el intercambio público e íntimo. Al respecto, en dos ocasiones las lágrimas adquieren el valor prosaico del dinero; una de 
ellas cuando su amigo llora y él no puede aunque quisiera, la sensación es que su amigo está "contando plata adelante de los pobres" (86), pero más específicamente porque, como señala el narrador, el personaje "considera las lágrimas como una especie de moneda, un instrumento de intercambio con el que compra o paga cosas (...) Con el llorar, por lo pronto, compra la admiración de su padre [y] [se] convierte en un trofeo, algo que su padre puede pasear por el mundo con un orgullo único" (32).

El dolor engulle a "La Felicidad”, está en su seno, “toda felicidad se erige alrededor de un núcleo de dolor intolerable, una llaga que la felicidad quizás olvide, eclipse o embellezca hasta volverla irreconocible pero que jamás conseguirá olvidar" (18). Por ello, tempranamente, el niño descubre que "su misión”, como las que tienen los superhéroes de sus historietas y luego los militantes guerrilleros, es revelar el dolor encubierto en esa felicidad, una misión que por otra parte, "no recuerda haber elegido" (18), sino que lo define de antemano, como aquel "llamado a" que precisaba la biografía de la Comandante Silvia.

De este modo, a lo largo de la novela se va conformando un halo de misticismo en torno al dolor -porque, "el dolor es lo excepcional" (11)-el cual impregna las imágenes del texto articulándolas a la figura capital del mártir: es el éxtasis que le provoca esa viñeta única e inusual del cómic en la que Súperman está a punto de morir ante la exposición a la kriptonita, porque además, a este niño "no son las proezas [de los superhéroes] lo que lo encandilan sino los momentos de defección" (9) y es tan excitante esa vulnerabilidad del hombre de acero, que "lo pierde" (12); es la imagen en la enciclopedia familiar que reproduce "las escalas sublimes de la pasión de Hércules (...) ardiendo para siempre en la pira" (119); son las fotos "de héroes, de mártires, de verdugos" (118) de La causa peronista, pero también la excitación eminentemente sexual que lo domina cada martes que espera, “con el corazón en la boca” (pág) la llegada de la revista (sudor de manos, hormigueo, euforia, mandíbula rechinante, crispación de los nervios, 116117) las imágenes que saturan de misticismo al dolor. Todas ellas cruzan como flechas el tiempo y "fermentan" (119) al unísono en una misma foto: aquella que muestra el cuerpo destrozado de la Comandante Silvia, la mártir por antonomasia en la novela. Porque en la medida en que, como enuncia el narrador, "el dolor es lo excepcional, por eso es lo que no se soporta", se 
establece una imbricación inconfesable entre esta pedagogía setentista de la sensibilidad y una pedagogía de la estética: el cuerpo es el punto ciego/ cegado por donde ambas pasan y se imprimen.

El goce estético del dolor que parece habitar en el sustrato profundo de un lazo social que, por otra parte, se genera por la coerción de una deuda impagable ${ }^{8}$, "la obligación (...) que nadie se puede dar el lujo de no tener" (84), la cual vuelve al cuerpo mercancía y a la muerte una forma de pago, despelleja verdaderamente a los utópicos 60 .

Mientras la figura encumbrada del mártir redime el saldo negativo, a la vez imprime un nuevo gravamen que compele a la congregación en torno a su iconografía para reinstituir el vínculo, la comunión del llanto, y de esta manera pone en evidencia una necrofilia argentina reverberante en el tiempo. El narrador afirma: "hacerse uno con el dolor es volverse indestructible" (100), modelizando, casi religiosamente, casi militarmente, ese supra-cuerpo fetichizado del mártir que trasciende la debilidad corpórea a través del dolor como redención. En el sustrato más impronunciable que guarece esta cita habita la parusía como relato pedagógico.

En este sentido, disiento con la lectura que propone Gersende Camenen (s/p), quien a través de la categoría freudiana de lo Unheimlich lee en la novela una transformación de lo familiar en siniestro, ajeno, desconocido. Creo, al contrario, que esta "inquietante extrañeza" a la que refiere se produce más bien en otro orden: se genera a partir de una expectativa de lectura frustrada cuando, en vez de toparnos en el texto con la consensuada reconstrucción de estos años desde la centralidad de sus utopías y proyectos de una humanidad bien pensante truncados por un afuera intempestivo, en verdad lo que hallamos es un mundo al cual el dolor y el terror le son inherentes y funcionales. En este punto, lo que queda en evidencia es que, en tanto constructo, el archivo genera sentidos "familiares", sedimenta un significado y una forma de interpretación muy difícil de transgredir, en tanto para hacerlo necesitamos a la misma vez usar y romper su propio aparato conceptual, su propia lengua. Tal vez por ello también toda lectura divergente cae bruscamente hacia el espacio de lo ominoso, cuando no, habida cuenta de ciertos sustratos político-culturales que la novela no deja de señalar, en el de la profanación. 
Un mundo desencantado, abatido por el propio peso de sus sueños se deja ver a través de las desavenidas relaciones entre padres/ hijos y hombre/ mujer: desde su abuelo, patriarca tiránico y arbitrario, hastiado de su vida, a la cual, sin embargo, no duda en condenar a otros, escandalizado por el pelo largo de su nieto al cual llama "mariconcito" (27), hasta su abuela, presa de la mezquindad machista de su esposo y habitada por una profunda soledad; pasando por la obligación insoportable de estar juntos, pero también, el sentirse "condenada" de su madre por estar separada, "vieja, usada, vacía (...) muerta en vida" (25). También la mucama suma su relato a este coro de penitentes, engañada por su amante a quien descubre casado. Por su parte, el padre también porta sus pequeñas miserias, entre ellas, el hecho de ser incapaz de legar a su hijo nada más ni mejor -a pesar de su esfuerzo por legarle la "sensibilidad”- que su desencuentro con las mujeres: "ese tono crispado que él más tarde aprende a reconocer como el sello de fábrica del estado en que queda su relación con las mujeres después de haber tenido hijos con ellas" (7-8). Sobre el fondo están los otros personajes, los hombres que lloran el abandono de sus mujeres (el amigo de su padre, el encargado del club, el amigo dejado por la novia chilena) y los adolescentes que desvirgan apresuradamente a sus novias en el cuarto de herramientas del jardín para luego abandonarlas (92).

Relatos de insatisfacción, cobardía, conformismo, la mayoría de ellos volcados como veneno en la oreja del personaje-confidente, ponen de manifiesto una fisura raigal en las filiaciones ${ }^{9}$ primarias y constituyentes de la sensibilidad, aquellas mismas que retornarán, cuando el marco jurídico y político de la democracia les otorgue su lugar legítimo en las Argentina de los 80, como el elemento fundamental para la reconstrucción social y política del país.

A contracorriente de este relato hegemónico en la posdictadura argentina, en la novela es precisamente desde el espacio del oïkos que el dolor se disemina e instituye como "escuela". A propósito de ello, cuando el niño a su vez vuelca ante el padre toda esta información que recepta, es decir, hace "su ofrenda”, la escena es por demás elocuente: “su padre es el superior ante el cual comparece regularmente, para informar, sin duda, aunque nunca le es fácil decidir hasta qué punto las historias que le lleva le importan" (29). Una escena de marcados matices castrenses donde el niño es sometido, cito, a 
"sesiones” ante un "superior”, donde se "reporta”, “informa” y “comparece” (29) señala una dinámica de disciplinamiento que estructura las relaciones.

Evidentemente en la novela, lo familiar no deviene inquietante sino que ya lo es.

\section{LO QUE NOS QUEDA}

Señala Hal Foster en su ensayo An Archival Impulse que la orientación del archivo es siempre más "legislativa" e "institutiva" que transgresora (5). Siguiendo esta línea de reflexión, proponíamos al comenzar que el archivo de los 60 y 70 genera un consenso medianamente estable y socialmente reproducible y apropiable respecto a formas de lidiar con ese pasado reciente. Ese consenso "legisla” no solo ciertas formas de la representación, sino que a la vez "instituye" a la representación misma como mecanismo nodal de su sutura. Ya en los inicios de la constitución de ese archivo, hacia 1984, la periodista y escritora María Moreno hacía referencia a un malestar respecto a las formas no representacionales a través de una crónica para El Porteño titulada "La tortura como pornografía", en ella advertía que, frente a la proliferación de testimonios y su uso amarillista y mercantil por parte de la prensa, "el arte no realista es percibido como un atentado a la evidencia del genocidio" 10 (Moreno 75).

En este sentido, Alejandra Oberti y Roberto Pittaluga advierten que la escena pública de la transición democrática argentina se pobló rápidamente de relatos del horror (16), aunque los años de la militancia armada sesentista y setentista recién comienzan a ser materia de interés significativo a partir de los 90 con publicaciones como la monumental La Voluntad. Una historia de la militancia revolucionaria en la Argentina tomo I, II y III, (1997 y 1998), o Monte Chingolo. La mayor batalla de la guerrilla argentina (2003). Relatos que recogen las voces de los testigos y militantes, insuflando nueva vida al testimonio -ya para los 90 desvinculado de su instrumentalidad jurídica directa- pero también al ensayo y el periodismo de investigación.

Deteniéndonos nuevamente en La Voluntad podemos observar de qué manera se entrelazan en ella la Historia y el testimonio en la conformación 
de una representación de alcances muy precisos. A través de 1915 páginas, reconstruye mediante materiales y documentos de archivo y el testimonio de veinticinco protagonistas-testigos (incluidos sus propios autores, Martín Caparrós y Eduardo Anguita), los hechos de la historia argentina entre 1966 y 1978, reescribiendo ya no una historia, como versa el subtítulo, sino evidentemente "la Historia", ahora desde las voces acalladas. Recobrando fragmentos y voces, el texto rearma, con el afán notorio de agotar la documentalización e interpretación de los acontecimientos, un friso total, monolítico, de la historia de estos años. Como habíamos dicho anteriormente, esta representación tiende, por un lado a modelizar una forma biográfica del militante apegada fuertemente a la figura de Rodolfo Walsh, que al repetirse e imprimirse sobre todos los casos testimoniantes, asienta finalmente una ejemplaridad. Pero por otro lado, también presiona al sentido hacia una constante cohesión interna, y esto queda en evidencia cuando se advierte que los testimonios que se recogen (la mayoría tomados de entrevistas hechas por el mismo Caparrós y Anguita) son incorporados a un relato en tercera persona que los noveliza, sofocando de este modo las eventuales diferencias entre sí. El sentido final de la representación pertenece más a esta tercera voz absorbente. En sintonía con esto, Beatriz Sarlo observa que:

Precisamente el discurso de la memoria y las narraciones en primera persona se mueven por el impulso de cerrar sentidos que se escapan; no solo se articulan contra el olvido, también luchan por un significado que unifique la interpretación. En el límite está la utopía del relato "completo", del cual no quede nada afuera (67).

Por ello, me interesa asirme de La Voluntad para tomarlo como texto referente del modelo o matriz de representación sedimentado en el archivo, el cual claramente se proyecta hacia la conformación de un relato de memoria reconstitutivo. Porque la novela, sin renunciar al alegato a favor de una comprensión del pasado, confronta esta matriz desde su búsqueda de otros materiales para el acceso a estos años (lo no dicho y lo insignificante para el archivo) y de otras formas compositivas que sostengan la apertura del sentido en tanto ejercicio de disenso (Rancière, Las paradojas) siempre en proceso.

En la primera parte hemos recorrido estas lecturas disensuales con que Historia del llanto aborda los 60 y 70 a contrapelo, pero, paralelamente, advertimos que la novela inquiere también una búsqueda propositiva que la lleva a convertirse en un texto-laboratorio que indaga en otras epistemologías del cuerpo y del texto. Allí, hace del con-tacto una vía para reformular la 
poética del cuerpo desde su coproducción incesante. En este sentido, es también un laboratorio en el que el propio texto -en la medida en que se plantea como una escritura/piel en con-tacto, en primera instancia, con la sinuosidad biobiográfica de esos cuerpos en devenir, pero en particular, en con-tacto con el presente-pasado- se ensaya fuera de sí desde la apertura a una significación como trabajo siempre en proceso.

¿Qué es lo propio de una escritura de la memoria? ¿Qué es lo propio de un testimonio? ¿De una biografía? La novela, manteniendo estas preguntas como coordenadas para su inteligibilidad (por algo la Historia y el testimonio están en su título) explora, por el contrario, las posibilidades de no pertenencia, de no propiedad de la palabra (literaria) al archivo en la medida en que se escurre de una representación "legislada” y apropiable para acercarse más a una presentación.

El presente continuo del texto es el tiempo de lo que (está) pasa(ndo) entre -los cuerpos, la escritura, los recuerdos y el ahora-, por tanto, se lanza a lo todavía no dicho/decible. Es el tiempo del vínculo, del con-tacto, para el cual el pasado no funciona como un mero repositorio fijo y/o neutro de hechos, disponible indistintamente a cualquier presente, sino como una fuerza que empuja a ese presente hacia el trabajo político.

A partir de la disonancia que emerge entre el título, Historia del llanto, y el subtítulo, Un testimonio, la novela nos sitúa en la tensión entre dos formas disímiles de afrontar los materiales del pasado: mientras la Historia nos remite al orden del método y lo disciplinar y a una accesibilidad "objetiva” a la fuente, el testimonio, por el contrario, se emplaza en el protagonismo de la primera persona, en la autoridad que confiere la intensidad y autenticidad de una experiencia vivida y transmutable en relato. Sus prerrogativas en cuanto a la credibilidad se sustentan en la correspondencia entre la experiencia vivida y la persona real que las cuenta, haciendo así de lo (auto)biográfico uno de los componentes más presentes en el género.

Ambas matrices se constituyeron en los espacios discursivos predilectos para la vuelta crítica al pasado durante la postdictadura en Argentina (Sarlo, Tiempo pasado). Y a pesar de sus divergencias, coincidieron en la finalidad explicativa-comprensiva y en la necesidad incontestable de reconstruir un sentido histórico para la reparación del trauma.

El testimonio, sin embargo, tuvo un plus de protagonismo. En paralelo a su entrada contundente al orbe de lo jurídico durante los juicios a las Juntas de 1985, éste se carga de valor social y jurídico a partir de su potencialidad reparadora (del trauma, de los lazos sociales quebrados) y restauradora (de 
las voces silenciadas). El testimonio carga con una verdad incontrovertible que la voz de la víctima, con su propia condición como reaseguro, aporta en la reconstrucción de los hechos.

$\mathrm{Al}$ respecto señala Sarlo:

El testimonio es una institución de la sociedad, que tiene que ver con lo jurídico y con un lazo social de confianza, como lo señaló Arendt. Ese lazo, cuando el testimonio narra la muerte o la vejación extrema, establece también una escena para el duelo, fundando así comunidad allí donde fue destruida (67).

En la medida en que, como sugiere Anna María Guasch, preguntarse por el archivo es también preguntarse por los mecanismos, soportes y reglas de su reproducción e impresión (Guasch 10), que la novela se refiera a la Historia y al testimonio desde su propio título, pone de realce el interés en problematizarlos y repensar asimismo desde la literatura el rol social -aquello a lo que Sarlo refiere como el "fundar comunidad", "establecer un lazo"-que estas matrices asumen.

Para que haya testimonio, debe haber un testigo. Pero, ¿quién es el testigo en Historia del llanto? La novela no solo rompe con uno de los códigos fundamentales del testimonio al emplear el tiempo presente, es decir, anula el hiato temporal que es también la distancia crítica, sino que además, escrita desde una tercera persona, suspende la voz testimonial por excelencia: la primera persona que "se hace cargo" de las experiencias referidas y sostiene la correspondencia entre hechos y relato. Por lo tanto, ya hay allí un descalce respecto de aquella figura que Agamben atribuye a Primo Levi, ser "el testigo perfecto" (Agamben, Homo Sacer III).

Si hay algo que nos permita abordar al personaje principal desde la figura del testigo, ello es sin duda su condición de "estar cerca” del dolor de los otros, porque, como refiere el narrador, tempranamente el niño se convierte en un receptáculo "del calvario del otro" (23). Pero la novela tampoco permite que nos instalemos muy cómodamente en esta clave de lectura, porque ese estar cerca no le significa, como sería de esperar, una comprensión o entendimiento, por lo tanto, tampoco hay allí ni “conmiseración” con ese sufrimiento, ni "responsabilidad” con su legado.

El niño encarna el rol del confidente. Como enuncia la primera frase de la novela, "a una edad en que los niños se desesperan por hablar, él puede pasarse horas escuchando" (7), es por ello "un oído absoluto" (22) y "en su presencia (...) los adultos se ponen a hablar" (23), vuelcan sus dolores, que 
son también sus secretos (porque "quien dice dolor dice secreto, dice doble vida" 61), cual "venenos dulces y exclusivos" (53) o "cosa infecta" (56) en su oído. Tanto su madre como ambos abuelos, la mucama, pero también los amigos del padre, el encargado del club, derraman sus secretos-dolores sobre el niño al cual -en tanto niño-parece quedarle siempre ajena la significación de lo recibido. Por otra parte, la escena de la escucha repite siempre la misma estructura: el adulto "invade” el espacio del niño (del juego, del baño, del recreo) con su apremio por desahogarse, ejerciendo así lo que desde su óptica se percibe como una microviolencia, reafirmada, como vimos, cuando a su vez el niño lleva toda esta información al padre cual “ofrenda”.

En ese marco, la novela instaura la sospecha acerca del lugar social fetichizado del testimonio, sobre el imaginario reconfortante que ve en él un dispositivo de entendimiento voluntarioso guiado por la llamada buena fe, capaz de recomponer la integridad del sujeto y dar reconocimiento a la experiencia traumática del otro.

Ya adulto, quienes se confiesen con él serán la ex-erpia y el oligarca torturado, ambos víctimas de la tortura y la laceración de sus órganos sexuales. Frente a este último, no solo hay una no compresión de sus palabras y del motivo por el cual las dice (57) sino una encolerización que lo lleva a fantasear un "repertorio de venganzas" (60), en donde, paradójicamente, aquel que se supone debe sentirse movilizado por su dolor, se transforma en verdad en su nuevo verdugo:

Liga su felicidad (...) con las cicatrices que el oligarca torturado esconde bajo el algodón de sus calzoncillos de marca, rastros de una pesadilla indecible que si no ha terminado, como es evidente, no es sólo por la alta probabilidad de que el uniformado que lo secuestró ande suelto por la calle (...) sino también porque todavía quedan en el mundo personas como él [el personaje principal] (...) [que] sólo parecen existir para enrostrarle al mundo la evidencia de su dicha (58-59).

La única que no se confiesa es precisamente la víctima final, el vecinoComandante Silvia, quien solo le relata un sueño premonitorio de los tiempos que se avecinan; un secuestro que termina en asesinato. Aun así, su cercanía, el haber visto sin comprender -un comprender que llega ya muy tarde al ver la foto en la revista-, es motivo para que el personaje se reproche no haberla salvado: "Se pregunta si, de haberlo sabido antes, hubiera podido salvarla, si él, y su triciclo y su bolsito Pan Am cargado con el repertorio de 
pasatiempos (...) hubieran impedido que la balearan, que la arrastraran boca abajo, como el pedazo de carne que es (...)" (123-124). La fantasía sexual y heroica contrarresta la intensa angustia de no haber podido/sabido: la sueña como un súcubo y en ese sueño, le ha dado asilo, "ha leído en los hollejos de sus dedos el secreto de su dolor" (123).

Estas “fallas", como grietas que se abren frente a la modelización del testigo, lo desmarcan del repertorio de piezas fijas que cada vez más se asientan en los relatos de la memoria. Como afirman Oberti y Pittaluga, figuras que, en tanto basadas en la heroicidad y el sacrificio impiden ver los matices: "sirven a las memorias que se basan en una repetición mecánica y ritualizada" (101). Y a este testigo nada lo aleja más de la heroicidad que el no "estar a la altura" de la historia, del compromiso exigido, de la entrega: "Es simple, no ha sabido lo que tenía que saber. No ha sido contemporáneo, no es contemporáneo, no lo será nunca. Haga lo que haga, piense lo que piense, es una condena que lo acompañará siempre" (124).

En este sentido, Historia del llanto interpela deliberadamente las formas representacionales de acceso a este pasado ya "sobreescrito" (Pauls 2010, s/p), en particular el testimonio por su estrecha relación con la verdad y su asunción del rol reparador, distanciándose de ellas en provecho de un protagonismo de la literatura como motor de necesario extrañamiento. Poniendo en un primer plano al relato como artefacto, el texto busca desautomatizar las lecturas cristalizadas y los moldes genéricos esperables, para acercarse al pasado prescindiendo de la confianza (y de la garantía) tanto en su transparencia como en su fijeza.

Para ello, el texto comienza con una imagen que funciona como hilo conductor de esta interpelación al archivo: el niño, enmascarado en un traje de Súperman y abstraído en su propia fantasía infantil de héroes y villanos, atraviesa con su triciclo la puerta balcón del departamento donde vive, haciendo estallar el vidrio y quedando desmayado. La imagen inaugura en la primera página de la novela la problematización de la transparencia de lo real como garante de un acceso incontaminado y realista al pasado, es decir, como posibilidad de reconstruir una representación acabada, total, fiel. La tensión entre lo real (el fondo de creciente violencia y militarización de estos años) y la ficción (en un primer lugar encarnada en la fantasía infantil que opera como un recodificador de lo real, pero más profundamente, una referencia al lugar de la literatura en relación con los discursos tradicionales de la memoria) pone en el centro de la escena la cuestión de la representación de ese pasado y las formas en que el archivo lo vuelve disponible para la 
sutura simbólica y social. La clave de lectura es enunciada por el propio narrador: "mantener lo real a distancia" (71 a 73), algo que sin embargo, como la misma novela expone a través de una economía narrativa que no hipoteca los sentidos acallando las contradicciones, no nos deja libres de riesgos: también ese mantener lo real a distancia puede hacer simplemente que no veamos lo evidente, que lleguemos tarde.

Si los discursos de la memoria parten de la exigencia de una correlación directa y fiel entre lo real acontecido y el relato que asume su reconstrucción (el pacto referencial) para producir representaciones (académicas, intelectuales, jurídicas, políticas, etc.) que funcionen socialmente de manera edificante, es decir, que generen la consumación de una/s verdad/es sobre la que construir una sanción y una sanación del pasado, por el contrario, la línea crítica que abre esta primera imagen de la novela anuncia ya un acercamiento al pasado desde lo astillado como imposible recuperación de una transparencia garante de la verdad. A partir de esta imagen, lo que queda para el resto de la novela que acaba de comenzar son solo astillas afiladas, fragmentos de una historia, los cuales constituirán sus modestos materiales de trabajo.

El propio Alan Pauls se refiere al uso de "fósiles" y "yacimientos" (Pauls 2010, s/p) para pensar desde allí el abordaje de los setenta, señalando más precisamente aquellos vestigios que fueron relegados porque son tan ínfimos que se escurren de la monumentalización de la historia y el testimonio, desbaratan cualquier intento de reificar el resto. En Historia del llanto son las lágrimas y las delicadas hebras de la piel los residuos que llegan, irrumpen, desde el fondo de aquellos años.

La novela se apropia de estos residuos lábiles como vías de acceso no tanto al recuerdo como sí al propio principio de olvido que domina toda representación: para constituirse, la memoria debe ejercer una selección de materiales que es también una jerarquización y un ordenamiento a través del cual se persigue, como señalaba Sarlo en el extracto citado anteriormente, conjurar la dispersión de los sentidos. Si en un primer momento la urgencia política y social por construir una memoria capaz de absorber y vehiculizar las luchas por la justicia tendió a generar relatos aglutinantes que minimizaran aquellos desacuerdos interpretativos que amenazaban con debilitar sus fuerzas, la novela, a contrapelo de ello, reabre el archivo de lecturas de estos años para amarrarse a lo olvidado y buscar allí latencias inquietantes entre el presente-pasado. La fuerza que comportan estos vestigios es precisamente la imposibilidad de ser restituidos a aquellos relatos empáticos, en general, a un imaginario de los setenta progresista y bien pensante, de manera que 
son astillas de un pasado que no pudo realizarse, que retornan y gravitan continuamente en el presente.

La incorporación del olvido como principio activo de todo relato de memoria nos alerta constantemente en la novela cuando la mirada se topa, siempre al azar, con varios signos de elipsis, “[...]”, que se hallan a lo largo de todo el texto y en diferentes ubicaciones. Éstos señalan un discurso citado pero también un trabajo de selección y omisión operado sobre él. Hay en ellos una carga de silencio, son indicios de algo irrecuperable que sin embargo está allí y genera significación desde su negatividad, impidiendo una confianza y cierre en lo dicho, e instalando así la sospecha. En tanto el archivo, como afirma Gausch, "no procede de manera amorfa o indeterminada, sino que nace con el propósito de coordinar un corpus dentro de un sistema o una sincronía de elementos seleccionados previamente en la que todos ellos se articulan" (10), este olvido debe estar oculto, naturalizado: el archivo esconde sus costuras y allí adquiere su fuerza de ley: fuera de él parece no quedar nada. Pero la novela opera al revés, exponiendo sus heridas.

Al trabajar con materiales signados por el malestar y la incomodidad, la representación da paso a la presentación: los vestigios desde los cuales la novela rearma su mirada de los setenta se inscriben en la lógica del síntoma como aquello que sobreviene, siguiendo a George Didi-Huberman, e "interrumpe el curso normal de las cosas según la ley, es decir, el curso normal de la representación" (63-64). El síntoma, como lo irresuelto, en tanto obedece a la lógica de la enfermedad, se manifiesta en el destiempo e importuna desestabilizando el archivo de imágenes y relatos cristalizados, funcionales, justamente, a una sanación (del cuerpo y del texto).

En su ensayo "El giro ético de la estética y la política", Rancière se pregunta por el estatuto del arte en estos tiempos de consenso e indistinción ética, observando que, peligrosamente, éste tiende a ceder ante una visión que lo "consagra al servicio del lazo social" (147), es decir, a reafirmar un reparto de lo sensible concertado, automatizado, fácilmente apropiable. Ante la crisis y el trauma, este tipo de arte estaría allí para representar, compensar la fisura de lo real generando formas de pertenencia: "devolverle a un mundo común el sentido perdido o [para] reparar las fallas del lazo social” (148). Pero Rancière está pensando más bien en otro lugar para el arte: un lugar de disenso al que sin duda remitimos Historia del llanto, donde éste no tiene como función dar sentido de los hechos a la sociedad, sino, por el contrario, generar nuevos cortes -“ambiguos, precarios, litigiosos" (161)que reconfiguren lo dado. 
Ese "pedazo de piel muerta" en que deviene lo previsto y consensuado del archivo solo se estremece con una caricia a contrapelo. El arte y la literatura se revisten allí de toda potencia disruptiva.

\section{BIBLIOGRAFÍA}

Agamben, Giorgio. Lo que queda de Auschwitz. El archivo y el testigo. Homo Sacer III. Valencia: Pre-Textos, 2009.

Anguita, Eduardo y Martín Caparrós. La Voluntad. Una historia de la militancia revolucionaria (Tomos I, II y III). Buenos Aires: Norma. Marzo 1997 (Tomo I). Octubre 1997 (Tomo II). Marzo 1998 (Tomo III).

Barriendos, Joaquín, "Reterritorializando los sesenta. Archivos, documentos y postestructuralismo en el museo de arte". Arte, archivo y tecnología. (Edit.) Castillo, Alejandra y Cristián Gómez-Moya. Santiago de Chile: Ediciones Universidad Finis Terrae. 2012. 121-141.

Camenen, Gersende, "Ser testimonio. Historia del llanto de Alan Pauls”, Amerique Latine.

Marzo 2009. htp://www.ameriquelatine.msh-paris.fr/spip.php?article278

Didi-Huberman, Georges. Ante el tiempo. Historia del arte y anacronismo de las imágenes. Buenos Aires: Adriana Hidalgo (editora), 2011.

Foster, Hal. “An archival impulse”. October. Vol. 110 (Autumn 2004): 3-22.

Foucault, Michel. La arqueología del saber. 1969. Buenos Aires: Siglo XXI, 2005.

Guasch, Anna María. Arte y archivo, 1920-2010. Genealogías, tipologías y discontinuidades. Madrid: Akal, 2011.

Moreno, María. "La tortura como pornografía”. 1984. El fin del sexo y otras mentiras. María Moreno. Buenos Aires: Sudamericana, 2002. 73-75.

Nancy, Jean-Luc. Archivida. Del sintiente y del sentido. Buenos Aires: Quadrata, 2013.

La comunidad inoperante. Santiago de Chile: LOM Ediciones, 2000.

Pauls, Alan. Historia del llanto. Un testimonio. Buenos Aires: Anagrama, 2007.

Entrevista "Se busca un lector incómodo". Revistaenie.clarin. Abril 2010. http:// edant.revistaenie.clarin.com/notas/2010/04/17/_-02182313.htm

Perlongher, Néstor. Prosa plebeya. Ensayos 1980-1992. Buenos Aires: Colihue, 2008.

Rancière, Jacques. "Las paradojas del arte político". El espectador emancipado. Buenos Aires: Manantial. 2010. 53-85.

"El giro ético de la estética y de la política”. El malestar en la estética. Buenos Aires: Capital Intelectual. 2011. 133-161.

Oberti, Alejandra y Roberto Pittaluga. Memorias en montaje. Escrituras de la militancia y pensamientos sobre la historia. Buenos Aires: El cielo por asalto, 2006.

Sarlo, Beatriz. Tiempo Pasado. Cultura de la memoria y giro subjetivo. Una discusión. Buenos Aires: Siglo XXI Editores, 2012. 